\title{
Controled Ovarian Stimulation with Urinary Gonadotrophins and Recombinant Gonadotrophins in Current Practice
}

\author{
CLAUDIA MEHEDINTU ${ }^{1}$, ELVIRA BRATILA ${ }^{1}$, LACRAMIOARA AURELIA BRINDUSE ${ }^{1 *}$, MONICA MIHAELA CIRSTOIU ${ }^{1}$, \\ COSTIN BERCEANU ${ }^{2}$, ALINA BORDEA ${ }^{1 *}$, DIANA ELENA COMANDASU ${ }^{1}$, ANDREEA CARP VELISCU ${ }^{1}$, OVIDIU BRATU $^{1}$, \\ CRISTIAN SAVA ${ }^{3}$, ADRIAN GHEORGHE BUMBU ${ }^{3}$ \\ ${ }^{1}$ Carol Davila University of Medicine and Pharmacy, 8 Eroii Sanitari Blvd., 050474, Bucharest, Romania \\ 2 University of Medicine and Pharmacy, 2 Petru Rares St., 200349, Craiova, Romania \\ ${ }^{3}$ University of Oradea, Faculty of Medicine and Pharmacy, 101 Decembrie Sq., 410068, Oradea, Romania
}

\begin{abstract}
The main objective of the this study is to compare the effectiveness of ovarian stimulation with recombinant gonadotrophins (FSHr) versus urinary gonadotrophins (hMG) within the number of oocytes obtained and the number of embryos in the two patient groups, according to age groups and associated pathologies. The study design was retrospective, monocentric. All patients (71) who have addressed the In Vitro Fertilization Clinic of the Prof. Dr. Panait Sirbu Clinical Obstetrics and Gynecology Hospital during 01.01.2010 and 31.12.2010 were included in this research. The total number of oocytes ( $8.5 \pm 3.9 \mathrm{vs} 5.7 \pm 3.9, p=0.045$ ), the number of fertilized oocytes $(7.5 \pm 3.6$ versus $3.6 \pm 2.8 p=0.004)$ and the number of embryos $(6.6 \pm 3.5$ versus $3.7 \pm 2.6, p=0.013$ ) were higher in women under 35 years of age treated with recombinant $F S H r$ compared to women treated with urinary gonadotrophins hMG. Ovarian stimulation with recombinant gonadotrophins provides a greater number of oocytes and a greater number of embryos in all patients, regardless of age and associated pathology. There are many variables that can influence the success rate, but the first variable that can be controlled is the choice of FSHr in daily clinical practice.
\end{abstract}

Keywords: ovarian stimulation, gonadotrophins, embryos

Assisted Human Reproduction (ART) is a science that many practitioners compare with an art because the choice of stimulation protocols and drugs according to the particularity of each infertility case requires experience and a clinical sense, which are not found in standardized protocols. The therapeutic approach varies between clinics, and the choice of ovarian stimulation drugs often depends on the clinician's experience with a particular product, as well as the results previously obtained in similar cases. However, ovarian stimulation in IVF is extensively studied and improved, with the goal of obtaining standardized protocols to ease the work of clinicians and maximize the response to treatment in each population of patients.

Stimulation protocols differ through the initiation of stimulation and the drugs used for inhibition and stimulation. The main parameter that influences the clinician in choosing the ovarian stimulation protocol is patient's age. Age and ovarian reserve (assessed by AMH serum anti-Mullerian hormone or AFC - antral follicle count) cannotbe changed [1-3] and are the only ones that provide an idea of the number of oocytes that could be harvested even before ovarian stimulation beginning. Starting from these two constants (age and ovarian reserve) that cannot be changed, each clinician chooses a stimulation protocol in favor of another, as well as the optimal dose of gonadotrophins for each patient [4-7].

Gonadotrophins have been used to treat infertility since the 1930's. The first preparations had animal origin, being followed by the appearance of human origin drugs (extracted from pituitary glands of human corpses). An important step forward was obtaining human menopausal gonadotrophins from the urine of postmenopausal women. Subsequently, highly purified urinary gonadotrophins produced by DNA technology appeared. Recombinant gonadotrophins are obtained by DNA technology using culture on hamster ovarian tissue and are characterized by a high specificity and purity close to $100 \%[8,9]$.

\section{Ovarian stimulation protocols and available medication}

ART specialists may choose to use a gonadotropinreleasing hormone (GnRH) agonist or a $\mathrm{GnRH}$ antagonist in order to suppress the LH (luteinizing hormone) peak. The treatment regimen may be started midway through the luteal phase, approximately one w eek after ovulation by administering a GnRH agonist, while gonadotrophin stimulation may be started after confirmation of pituitary down-regulation occurrence (long protocol) $[10,11]$. In case of short protocol, ovarian stimulation with gonadotrophins starts from day 2-3 of the menstrual cycle, and an agonist or GnRH antagonist can alternatively be used to prevent LH peak [12]. Substances used for stimulation are urinary or recombinant FSH, urinary or recombinant FSH and LH.

Until the appearance of GnRH antagonists, the long protocol was the most frequently used. Subsequently, because of the longer treatment duration, the higher doses of gonadotrophins required and the risk of hyperstimulation, the long protocol fell to second place in favor of the short $\mathrm{GnRH}$ antagonist protocol. Antagonist stimulation remains the first option for poor responders, primarily to avoid the suppressive effects that agonists have on follicular response and secondly to prevent premature LH peak, often seen in GnRH agonist alone stimulation [13].

Urinary hMG (human menopausal gonadotropin), derived from postmenopausal women's urine was for a long time the standard product used in controlled ovarian stimulation and ovulation induction. It contains both FSH (follicle stimulating hormone) and LH, but also other potentially biologically active urinary proteins. Some of the biological activity of LH in hMG is derived from hCG (human 
chorionic gonadotropin), resulting in a variation in concentration from one production batch to another, which causes differences in treatment response. Human chorionic gonadotrophin, a natural hormone found in postmenopausal females' urine [14], has an important contribution to LH activity. LH and hCG act on the same receptor by activating different pathways of signals transmission. The role of LH or hCG in addition to ovarian stimulation with FSH is highly debated lately [15-17].

Menopur ${ }^{\circledR}$ (menotropin) belongs to the group of therapeutic agents called human menopausal gonadotrophins. It is a highly purified urinary product containing both FSH and similar LH activity. It is an effective option in controlled ovarian stimulation in assisted human reproductive techniques and induction of ovulation in patients with anovulatory cause infertility. Menopur is associated with a different endocrine profile compared to FSHr in terms of serum levels of FSH, androgen and estradiol. Used in IVF / ICSI cycles, some studies show similar performance to the ones of FSHr in terms of pregnancy rate, but with a lower number of oocytes retrieved. Compared to $\mathrm{FSHr}$, it appears that ovarian stimulation with menotropin is associated with a lower risk of ovarian stimulation [18]. FSHr does not contain exogenous proteins and shows the same hormonal concentration regardless of the production group. These features are responsible for providing a steady response in ovarian stimulation with $\mathrm{FSHr}$ [19].

LH and hCG are heterodimeric glycoprotein hormones acting on the same receptor (LHCGR). These gonadotrophins have long been considered molecularly equivalent. Subsequently it has been shown to cause distinct intracellular signals. hCG is more potent than LH in the production of APMc (cyclic adenosine monophosphate), while LH is more potent in preferential activation of ERK $1 / 2$ and AKT. In vivo, both FSH and LH act synergistically in stimulating folliculogenesis and ovulation [20]. In controlled ovarian protocols, the clinician determines the FSH dose, depending on the patient's characteristics, required to obtain a desired response and may add LH or hCG [21-25].

\section{FSHr or HMG - What do we already know?}

Currently, the pharmacological products market offers a wide range of gonadotrophins: urinary, recombinant or various combinations of these. This allows personalization of treatment regimens. These gonadotrophins present different kinetic models both in vitro and in vivo. It is recently attempted to demonstrate the ideal combination of gonadotrophins in order to achieve a maximum result. There are numerous studies and articles that desire to show the superiority of a gonadotrophin in favor of others in terms of response rate, number of oocytes, number of blastocysts, number of biochemical, clinical and term pregnancies. However, there are still many controversies about the use of recombinant human gonadotrophins or urinary gonadotrophins (hMG) in order to achieve an optimal outcome [26-28].

The main objective of the study is to compare the effectiveness of ovarian stimulation with FSHr versus urinary HMG within the number of oocytes obtained and the number of embryos in the two patient groups, according to age groups and associated pathologies.

\section{Experimental part}

Material and method

The present article represents a retrospective study performed in the In vitro Fertilization Clinic of the Clinical Prof. Dr. Panait Sirbu Obstetrics and Gynecology Hospital, during 01.01.2010 and 31.12.2010. After that year, the use of urinary gonadotrophins exclusively in in vitro fertilization cycles was abandoned.

\section{Inclusion criteria}

All patients who have addressed the In Vitro Fertilization Clinic of the Prof. Dr. Panait Sirrbu Clinical Obstetrics and Gynecology Hospital, Bucharest during 01.01.2010 and 31.12.2010, regardless of pathology were included into the study. Exclusion criteria consisted in an AMH level below 1 $\mathrm{ng} / \mathrm{mL}$, age over 43 years, and diagnosed endometriosis.

\section{Statistical analysis}

The results are presented as absolute and percentage frequencies for qualitative variables and as averages and standard deviation for quantitative variables. Betweengroup differences in continuous and non-continuous variables were assessed using t-test and chi-square test, respectively. P-values were calculated two-sided, and $p<0.05$ was considered statistically significant. All analyses were performed using the software SPSS 23.0.

\section{Results and discussions}

A total 71 women were included, 43 in group A (FSHr) and 28 in group $B$ (hMG/Menopur). Patient distribution by age and by pathology did not differ significantly between Gonal and Menopur treatment groups, as it is presented in table 1.

The total number of oocytes ( $8.5 \pm 3.9$ vs. $5.7 \pm 3.9$; $p=0.045)$, number of fertilised oocytes (7.5 \pm 3.6 vs. $3.6 \pm 2.8 ; p=0.004)$ and number of embryos (6.6 $6 \pm 3.5$ vs. $3.7 \pm 2.6 ; p=0.013$ ) were higher for w omen under 35 years old treated with FSHr comparative with women treated with hMG. The number of fertilised oocytes was statistically significant higher for women with feminine pathology included in Group A (FSHr) (6.4 \pm 3.8 vs. $3.5 \pm 2.2 ; p=0.022)$. The number of fertilised oocytes ( $6.5 \pm 3.8$ vs. $2.8 \pm 1.5$; $p=0.007)$ and number of embryos (5.8 \pm 3.5 vs. $2.8 \pm 1.5$; $p=0.017$ ) were higher for women with tubal pathology treated with FSHr. Results are presented in table 2.

Ovarian stimulation in IVF procedures is a permanently developing and highly improved recently subject, which becomes more and more standardized in order to ease the

\begin{tabular}{|c|c|c|c|c|c|}
\hline \multirow{2}{*}{ Variable } & \multicolumn{2}{|c|}{ Group A (FSHr) } & \multicolumn{2}{c|}{ Group B (hMG/Menopur) } & \multirow{2}{*}{ p value } \\
\cline { 2 - 5 } & No. & $\%$ & No. & $\%$ & \\
\hline Age & & & & & \\
<35 years old & 25 & 58.1 & 14 & 59.0 & 0.109 \\
$\geq 35$ years old & 18 & 41.9 & 14 & $50.0 \%$ & 0.596 \\
\hline Pathology & & & & & \\
feminine & 23 & 53.5 & 13 & 46.4 & 0.134 \\
tubal & 17 & 39.5 & 11 & 39.3 & 0.345 \\
ovarian & 11 & 25.6 & 6 & 21.4 & 0.332 \\
endometriosis & 2 & 4.7 & 0 & 0.0 & 1.0 \\
male & 9 & 20.9 & 9 & 32.1 & 1.0 \\
combined & 4 & 9.3 & 1 & 3.6 & 0.375 \\
unknown & 7 & 16.3 & 5 & 17.9 & 0.774 \\
\hline
\end{tabular}

Table 1

PATIENT'SCHARACTERISTICS 


\begin{tabular}{|c|c|c|c|c|}
\hline Variable & Characteristics & Group A (FSHr) & Group B (hMG/Menopur) & $\mathrm{p}$ value \\
\hline \multirow[b]{2}{*}{ Total number of oocytes } & $\begin{array}{l}\text { Age } \\
<35 \text { years old } \\
\geq 35 \text { years old }\end{array}$ & $\begin{array}{l}8.5 \pm 3.9 \\
6.0 \pm 5.1\end{array}$ & $\begin{array}{l}5.7 \pm 3.9 \\
5.7 \pm 3.8\end{array}$ & $\begin{array}{l}0.045 \\
0.861\end{array}$ \\
\hline & $\begin{array}{l}\text { Pathology } \\
\text { feminine } \\
\text { tubal } \\
\text { ovarian } \\
\text { male } \\
\text { unknown }\end{array}$ & $\begin{array}{l}6.9 \pm 4.3 \\
7.1 \pm 4.3 \\
6.8 \pm 4.3 \\
6.8 \pm 4.3 \\
9.7 \pm 6.1\end{array}$ & $\begin{array}{l}5.2 \pm 3.6 \\
4.8 \pm 3.8 \\
3.8 \pm 2.8 \\
6.0 \pm 4.4 \\
7.6 \pm 2.8\end{array}$ & $\begin{array}{l}0.213 \\
0.172 \\
0.153 \\
0.710 \\
0.491\end{array}$ \\
\hline \multirow[b]{2}{*}{$\begin{array}{l}\text { Number of fertilised } \\
\text { oocytes }\end{array}$} & $\begin{array}{l}\text { Age } \\
<35 \text { years old } \\
>35 \text { years old }\end{array}$ & $\begin{array}{l}7.5 \pm 3.6 \\
5.8 \pm 4.6\end{array}$ & $\begin{array}{l}3.6 \pm 2.8 \\
5.6 \pm 4.0\end{array}$ & $\begin{array}{l}0.004 \\
0.815\end{array}$ \\
\hline & $\begin{array}{c}\text { Pathology } \\
\text { feminine } \\
\text { tubal } \\
\text { ovarian } \\
\text { male } \\
\text { unknown }\end{array}$ & $\begin{array}{l}6.4 \pm 3.8 \\
6.5 \pm 3.8 \\
7.1 \pm 3.9 \\
6.5 \pm 4.1 \\
7.9 \pm 5.7 \\
\end{array}$ & $\begin{array}{l}3.5 \pm 2.2 \\
2.8 \pm 1.5 \\
3.7 \pm 3.0 \\
6.8 \pm 5.2 \\
5.0 \pm 1.7 \\
\end{array}$ & $\begin{array}{l}0.022 \\
0.007 \\
0.095 \\
0.896 \\
0.430\end{array}$ \\
\hline \multirow[b]{2}{*}{$\begin{array}{l}\text { Ratio fertilized } \\
\text { oocytes/total oocytes }\end{array}$} & $\begin{array}{l}\text { Age } \\
<35 \text { years old } \\
\geq 35 \text { years old }\end{array}$ & $\begin{array}{l}0.86 \pm 0.1 \\
0.94 \pm 0.1\end{array}$ & $\begin{array}{l}0.89 \pm 0.3 \\
0.96 \pm 0.1\end{array}$ & $\begin{array}{l}0.700 \\
0.691\end{array}$ \\
\hline & $\begin{array}{l}\text { Pathology } \\
\text { feminine } \\
\text { tubal } \\
\text { ovarian } \\
\text { male } \\
\text { unknown }\end{array}$ & $\begin{array}{l}0.89 \pm 0.1 \\
0.89 \pm 0.1 \\
0.96 \pm 0.1 \\
0.96 \pm 0.1 \\
0.80 \pm 0.2\end{array}$ & $\begin{array}{c}0.89 \pm 0.3 \\
0.86 \pm 0.3 \\
1.0 \pm 0.0 \\
1.00 \pm 0.0 \\
0.86 \pm 0.2\end{array}$ & $\begin{array}{l}0.990 \\
0.752 \\
0.139 \\
0.245 \\
0.582 \\
\end{array}$ \\
\hline \multirow[t]{2}{*}{ Number of embryos } & $\begin{array}{l}\text { Age } \\
<35 \text { years old } \\
\geq 35 \text { years old }\end{array}$ & $\begin{array}{l}6.6 \pm 3.5 \\
5.3 \pm 4.4\end{array}$ & $\begin{array}{l}3.7 \pm 2.6 \\
4.5 \pm 2.5\end{array}$ & $\begin{array}{l}0.013 \\
0.592 \\
\end{array}$ \\
\hline & $\begin{array}{l}\text { Pathology } \\
\text { feminine } \\
\text { tubal } \\
\text { ovarian } \\
\text { male } \\
\text { unknown }\end{array}$ & $\begin{array}{l}5.5 \pm 3.7 \\
5.8 \pm 3.5 \\
5.6 \pm 4.0 \\
6.2 \pm 3.6 \\
7.3 \pm 5.6\end{array}$ & $\begin{array}{l}3.5 \pm 2.2 \\
2.8 \pm 1.5 \\
3.7 \pm 3.0 \\
5.0 \pm 3.2 \\
5.0 \pm 1.4\end{array}$ & $\begin{array}{l}0.096 \\
0.017 \\
0.314 \\
0.492 \\
0.449\end{array}$ \\
\hline \multirow[b]{2}{*}{$\begin{array}{l}\text { Number of transferred } \\
\text { embryos class A }\end{array}$} & $\begin{array}{l}\text { Age } \\
<35 \text { years old } \\
\geq 35 \text { years old }\end{array}$ & $\begin{array}{l}2.0 \pm 1.2 \\
1.8 \pm 1.3\end{array}$ & $\begin{array}{l}1.4 \pm 1.4 \\
1.8 \pm 1.4\end{array}$ & $\begin{array}{l}0.136 \\
0.987\end{array}$ \\
\hline & $\begin{array}{c}\text { Pathology } \\
\text { feminine } \\
\text { tubal } \\
\text { ovarian } \\
\text { male } \\
\text { unknown }\end{array}$ & $\begin{array}{l}2.0 \pm 1.2 \\
2.0 \pm 1.1 \\
2.0 \pm 1.3 \\
1.7 \pm 1.4 \\
1.7 \pm 1.4 \\
\end{array}$ & $\begin{array}{l}1.9 \pm 1.4 \\
1.7 \pm 1.4 \\
2.3 \pm 1.5 \\
1.3 \pm 1.4 \\
1.2 \pm 1.3 \\
\end{array}$ & $\begin{array}{l}0.865 \\
0.566 \\
0.645 \\
0.624 \\
0.530 \\
\end{array}$ \\
\hline \multirow{2}{*}{$\begin{array}{c}\text { Number of transferred } \\
\text { embryos }\end{array}$} & $\begin{array}{l}\text { Age } \\
<35 \text { years old } \\
\geq 35 \text { years old }\end{array}$ & $\begin{array}{l}2.2 \pm 1.1 \\
2.2 \pm 1.2\end{array}$ & $\begin{array}{l}2.1 \pm 1.3 \\
2.4 \pm 1.8\end{array}$ & $\begin{array}{l}0.745 \\
0.798\end{array}$ \\
\hline & $\begin{array}{l}\text { Pathology } \\
\text { feminine } \\
\text { tubal } \\
\text { ovarian } \\
\text { male } \\
\text { unknown }\end{array}$ & $\begin{array}{l}2.3 \pm 1.1 \\
2.4 \pm 0.8 \\
2.1 \pm 1.3 \\
2.2 \pm 1.3 \\
2.0 \pm 1.3\end{array}$ & $\begin{array}{l}2.4 \pm 1.3 \\
2.3 \pm 1.4 \\
2.3 \pm 1.5 \\
2.2 \pm 1.9 \\
2.0 \pm 1.9\end{array}$ & $\begin{array}{l}0.765 \\
0.849 \\
0.733 \\
1.000 \\
1.000\end{array}$ \\
\hline
\end{tabular}

work of the clinician and enhance patient's comfort by achieving the optimal outcome for each patient category. The most important part of the ovarian stimulation process is choosing the protocol type and dose with maximum efficacy, and minimize undesirable effects, especially ovarian hyperstimulation syndrome. There are no clear recommendations for choosing the stimulation protocol, so every clinician is based on the experience and the peculiarity of each case. Age and ovarian reserve are the main factors influencing choice of a stimulation protocol over another, as well as the response to ovarian stimulation. The protocols are different with respect to the substances used for inhibition and the moment of stimulation initiation. Substances used for stimulation are urinary or recombinant FSH and urinary or recombinant LH. In the literature, there are many controversies regarding the superiority of FSHr.

The use of FSHr determined a higher rate of pregnancy compared to urinary products, according to a meta-analysis that increased the FSHr's use in the world by 5-fold [28,29]. FSH is essential in controlled ovarian stimulation in assisted human reproduction procedures. On the other hand, the importance of supplementation with LH is strongly debated. Recent meta-analysis show that ovarian stimulation with hMG would result in a higher rate of pregnancy than when FSHr is used in short antagonist protocols. Although there are few randomized studies comparing $\mathrm{FSHr}$ efficacy with $\mathrm{hMG}$ efficacy in controlled ovarian stimulation, they present comparable results between the two pharmacological agents in terms of oocyte counts, blastocyst count, and pregnancy rate [3030-32].

A meta-analysis published in 2008 shows similar results in terms of patient safety (ovarian hyperstimulation syndrome) and clinical outcomes (pregnancy rate) in both ovarian stimulation with $\mathrm{hMG}$ and ovarian stimulation with FSHr [28]. Another meta-analysis of seven randomized trials 
involving 2159 patients showed a $4 \%$ higher pregnancy rate in the hMG-stimulated group of patients in the longagonist protocol versus the FSHr-stimulated group of patients in the same type protocol [32]. Another metaanalysis published in 2017, which included 20 prospective studies and 5512 patients showed a significantly higher number of oocytes in the FSHrgroup than in the hMG group $(p<0.001)$. Four of these studies used a short antagonist protocol and 16 studies used long agonist protocol. Within the short antagonist protocol, a higher number of oocytes was obtained [33]. An older study involving 324 patients compared FSHr's efficacy with HMG in ovarian stimulation for IVF, resulting in a higher implantation rate and a higher number of pregnancies in the FSHr group [34].

Another retrospective study published in 2018 that included 579 patients shows that there is no statistical difference in ovarian stimulation with FSHr / HMG in terms of pregnancy rate. The same study shows a higher number of days of stimulation in FSHr-treated patients [35]. Regarding oocyte quality, a prospective 50-cycle ICSI male infertility study evaluated 363 MII oocytes. These patients were divided into two groups according to the ovarian stimulation protocol: FSHr and hMG. The rate of oocytes with normal morphology was significantly higher in the hMG group than in the FSHr group [36].

With regards to women with polycystic ovarian syndrome (SOPC), a meta-analysis of 14 studies including 1,726 women comparing FSHr with urinary gonadotrophins showed no difference in the rate of pregnancy and the risk of hyperstimulation syndrome. The authors recommend the choice of stimulation medications in these patients based on financial considerations [37].

The importance of the number of oocytes results from a study of 400,135 in vitro fertilization cycles showing that there is an important association between the number of oocytes and the LBR (live birth rate), so a higher number of oocytes is close to any age synonymous with a better rate of pregnancy [38].

The existence of controversy over the choice of ovarian stimulation medications is obvious. It is encouraging and positive that there is controversy in assisted human reproduction because some controversies could be viewed retrospectively as pillars to support progress in the field. The lack of a clear recommendation regarding the choice of a gonadotrophin in order to maximize success in clinical practice is what led to the curiosity of evaluating personal results.

Following ovarian stimulation with $\mathrm{FSH}$, we obtained a higher number of oocytes and a higher number of embryos in female pathology patients. As many studies show, FSHr does not contain exogenous proteins and shows the same hormonal concentration regardless of the production group. These advantages ensure ovarian stimulation with FSHr to provide a steady response. Therefore, the exclusive use of hMG in controlled ovarian cycles has experienced a decline with the occurrence of recombinant products. Our results are similar to most studies in the literature.

Clinicians may choose to use a GnRH agonist or GnRH antagonist in order to suppress the LH peak, choose to transfer embryos on day 3 or as blastocyst.

\section{Conclusions}

There are many factors that can influence implantation (endometriosis, adenomyosis, various methods of supporting the luteal phase, the number of embryos transferred and whether they are fresh or cryopreserved, etc.), but what is known for certain is that an increased number of oocytes is correlated with a higher rate of pregnancy.
According to the results, ovarian stimulation with recombinant gonadotrophins provides a greater number of oocytes and a higher number of embryos in all patients, regardless of age and associated pathology. A major goal of assisted human reproductive treatments is to control as many of the existing variables as possible in order to maximize success. Considering that, the first variable that can be controlled is the choice of FSHr in daily clinical practice.

\section{References}

1.BUMBU, A., NACER, K., BRATU, O.; et al., Proceedings of the 14th National Congress of Urogynecology and the National Conference of the Romanian Association for the Study of Pain, 2017, p. 82.

2.MEHEDINTU, C., ANTONOVICI, M., BRINDUSE L., BRATILA, E., STANCULESCU, R., BERCEANU, C., BRATU, O., PITURU, S., ONOFRIESCU, M., MATASARIU, D.R., Rev. Chim.(Bucharest), 69, no. 3, 2018, p. 581.

3.BODEAN, O., BRATU, O., BOHILTEA, R., MUNTEANU, O., MARCU, D., ARSENIE SPINU, D., VACAROIU, I.A., SOCEA, B., DIACONU, C.C., FOMETESCU GRADINARU, D., CIRSTOIU, M., Rev. Chim. (Bucharest), 69, no. 6, 2018, p. 1411.

4.INGE, G.B., BRINSDEN, P.R., ELDER, K.T., Hum. Reprod., 20, 2005, p. 588.

5.VELEVA, Z., JARVELA, I.Y., NUOJUA-HUTTUNEN, S, MARTIKAINEN, H., TAPANAINEN, J.S., Fertil. Steril., 83, 2005, p. 1384.

6.PATRIZIO, P., VAIARELLI, A., LEVI SETTI, P.E., TOBLER, K.J., SHOHAM, G., LEONG, M., SHOHAM, Z., Reprod. Biomed., 30, no. 6,2015, p. 581.

7.EL-TOUKHY, T., KHALAF, Y., HART, R., TAYLOR, A., BRAUDE, P., Hum. Reprod., 17, 2002, p. 1519.

8.LUNENFELD, B., Hum. Reprod., 10, 2004, p. 453.

9.HOWLES, C.M., EZCURRA, D., HOMBURG, R., Rev. Endocrinol. Metab., 7, 2012, p. 319.

10.TROUNSON, A., LEETON, J., BESANKO, M., WOOD, C., CONTI, A., Br. Med. J. (Clin. Res. Ed.), 286, no. 6368, 1983, p. 835.

11.TROUNSON, A., MOHR, L., Nature, 305, 1983, p. 707.

12.MESSINIS, I.E., TEMPLETON, A.A., Hum. Reprod., 5, 1990, p. 153. 13.HEDON, B., OUT, H.J ., HUGUES, J.N., CAMIER, B., COHEN, J., LOPES, P., ZORN, J.R., VAN DER HEIJ DEN, B., COELINGH BENNINK, H.J.T., Hum. Reprod., 10, 1995, p. 3102.

14.BUMBU, A., PASCA, B., TIT, D.M., BUNGAU, S., BUMBU, G., Farmacia, 64, no. 3, 2016, p. 419.

15.GIUDICE, E., CRISCI, C., ESHKOL, A., PAPOIAN, R. Hum Reprod., 9, 1994, p. 2291.

16.SANTI, D., CASARINI, L., ALVIGGI, C., SIMONI, M., Front Endocrinol. (Lausanne),1, no. 8, 2017, p. 114. doi: 10.3389/ fend0.2017.00114. e.

17.GIUDICE, E., CRISCI, C., ALTAROCCA, V., O'BRIEN, M., J. Clin. Res., 4, 2001, p. 27.

18.DEEKS, E.D., Clin. Drug. Investig., 2018. doi: 10.1007/s40261-0180703-8.

19.LOUMAYE, E., CAMPBELL, R., SALAT-BAROUX, J. Hum Reprod., 1, 1995, p. 188.

20.STOICESCU, M., BUNGAU, S., TIT,D. M., MUTIU,G., PURZA, L., IOVAN, C., POP, O.L., Rom. J. Morphol. Embriol., 58, no. 4, 2017, p. 1429.

21.SCOLI, M., FANELLI, F., SEGALOFF, D.L., Endocr. Rev., 23, no. 2, 2002, p. 141.

22.CASARINI, L., LISPI, M., LONGOBARDI, S., MILOSA, F., LA MARCA, A., TAGLIASACCHI, D., et al. PLoS One, 7, no. 10, 2012.

23.CASARINI, L., RICCETTI, L., DE PASCALI, F., NICOLI, A., TAGLIAVINI, S., TRENTI, T., et al. Mol. Cell. Endocrinol., 422, 2016, p. 103.

24.TIT, D.M., BUNGAU, S., IOVAN, C., NISTOR CSEPPENTO, D.C., ENDRES, L., SAVA, C., SABAU, A.M., FURAU, G., FURAU, C., JCM, 7, no. 10, 2018, p. 297. https://doi.org/10.3390/jcm7100297

25.TIT, D.M., PALLAG, A., IOVAN, C., FURAU, G., FURAU, C., BUNGAU, S., Iran. J. Public Health, 46, no. 11, 2017, p. 1128. 
26.WONG, K.M., MASTENBROEK, S., REPPING, S., Fertil, Steril., 102, no. 1,2014, p. 19.

27.OLDFARB, J.M., DESAI, N., Fertil. Steril., 80, 2003, p. 1094.

28.VAN WELY, M., WESTERGAARD, L.G., BOSSUYT, P.M.M., VAN DER VEEN, F., Fertil. Steril., 80, 2003, p. 1086.

29.DAYA, S. Fertil. Steril., 77, 2002, p. 711.

30.AL INANY, H.G., ABOU SETTA, A.M., ABOULGHAR, M.A., MANSOUR, R.T.S.G., Reprod. Biomed., 16, 2008, p. 81.

31.COOMARASAMY, A., AFNAN, M., CHEEMA, D., VEEN, F., BOSSUYT, P.M.M., Wely, M., Hum. Reprod., 23, 2008, p. 310.

32.DIMITRIU, M.C.T., IONESCU, C.A., GHEORGHIU, D.C., SOCEA, L.I., BRATU, O.G., CONSTANTIN, V.D., PLES, L., NEACSU, A., BOBIC, S., SOCEA, B., Rev. Chim.(Bucharest), 69, no. 9, 2018, p. 2391.

33.SANTI, D., CASARINI, L., ALVIGGI, C., SIMONI, M., Front. Endocrinol, (Lausanne)., 8, 2017, p. 114.
34.GOLDFARB, J.M., DESAI, N., Fertil. Steril., 80, 2003, p. 1094. 35.SAHMAY, S., USTA, T.A., ZEBITAY, G., SENTURK, L.M., ORAL, E., OCAL, P., IDIL, M., IREZ, T., Minerva Ginecol., 66, no. 4, 2014, p. 341.

36.TAHERI, F., ALEMZADEH MEHRIZI, A., KHALILI, M.A., HALVAEI, I., Taiwan J. Obstet. Gynecol., 57, no. 2, 2018, p. 205. doi: 10.1016/ j.tjog.2018.02.007.

37.WEISS, N.S., NAHUIS, M., BAYRAM, N., MOL, BW., VAN DER VEEN, F., VAN WELY, M., Cochrane Database Syst. Rev., 9, no. 9, 2015, CD010290. doi: 10.1002/14651858.CD010290.pub2.

38.SUNKARA， S.K., RITTENBERG， V., RAINE-FENNING, N., B HATTACHARYA, S., ZAMORA, J., COOMARASAMY, A., Hum. Reprod., 26, no. 7, 2011, p. 1768. doi: 10.1093/humrep/der106. Epub 2011 May 10.

Manuscript received: 21.07 .2018 